\title{
UMIĘDZYNARODOWIENIE PROCESÓW KONTROLI KONCENTRACJI PRZEDSIĘBIORCÓW
}

\begin{abstract}
WSTĘP
Przedsiębiorcy rozwijają się drogą naturalnej ekspansji albo w drodze przejmowania innych przedsiębiorców ${ }^{1}$ (np. konkurentów czy kontrahentów). O ile jednak wzrost organiczny jest tylko $\mathrm{w}$ niewielkim zakresie poddany kontroli władz publicznych, o tyle łączenie się przedsiębiorców, w określonych sytuacjach, wymaga autoryzacji ze strony powołanego organu administracji publicznej. W ostatnim okresie możemy zaobserwować, że problematyka publicznoprawnej interwencji w procesy koncentracyjne przestała być jedynie domeną przepisów krajowych, ale ulega umiędzynarodowieniu. Przełamując antagonizmy krajowe, a często i sprzeczne interesy, organy ochrony konkurencji z wielu krajów podejmują wysi1ki mające na celu intensyfikację współpracy. Orędownikami takiej współpracy są także przedsiębiorcy działający w skali globalnej, dla których istnienie odrębnych oraz odmiennych przepisów krajowych o kontroli koncentracji stanowi istotny koszt transakcyjny. Wzrastająca współpraca międzynarodowa w dziedzinie prawa konkurencji powiązana jest z postępującym procesem konwergencji krajowych ustawodawstw antymonopolowych. Proces ten zakłada stopniowe zbliżanie się przepisów prawnych oraz administracyjnej praktyki ich stosowania. Proces umiędzynarodowienia współpracy oraz konwergencji prawnej i administracyjnej wzajemnie się uzupełniają i wzmacniają.
\end{abstract}

* Adiunkt w Zakładzie Prawa Administracyjnego, Instytut Nauk Prawnych PAN.

1 Nauka ekonomii posługuje się pojęciem przedsiębiorstwa, natomiast prawo oraz literatura prawnicza używają pojęcia przedsiębiorcy. $Z$ tego względu określenie „przedsiębiorstwo” używane jest jedynie w sytuacji relacjonowania ustaleń teoretycznych z zakresu ekonomii oraz w przypadku, kiedy ustawodawca wyraźnie posługuje się tym terminem, np. tajemnica przedsiębiorstwa, nabycie części mienia przedsiębiorstwa czy na gruncie prawa unijnego. 
Przedmiotem artykułu jest analiza zjawiska umiędzynarodowienia procesów kontroli koncentracji przedsiębiorców. Rozpoczyna go krótka prezentacja założeń publicznoprawnej interwencji w koncentrację przedsiębiorców w gospodarce. $\mathrm{Na}$ stępnie wskazane zostały przyczyny intensyfikacji i rozwoju współpracy międzynarodowej w sprawach koncentracji. Zjawisko to stanowi fenomen ostatnich lat i wciąż pozostaje aktualne, co wywołuje wiele interesujących zagadnień $\mathrm{z}$ zakresu prawa antymonopolowego. Kolejno przedstawiona została ogólna klasyfikacja forów i środków wspólpracy międzynarodowej w sprawach kontroli koncentracji. Stworzyło to odpowiednie ramy do omówienia najważniejszych instytucji, organizacji i innych środków wykorzystywanych do wspólpracy międzynarodowej w sprawach kontroli łączenia przedsiębiorców.

\section{CEL KONTROLI KONCENTRACJI PRZEDSIĘBIORCÓW}

W warunkach konkurencji doskonałej na rynku jest potencjalnie miejsce dla każdego jego uczestnika. Każdy może w dowolnej chwili wejšć i wyjść na rynek, liczba aktywnych przedsiębiorców jest zaś nieograniczona. Te założenia szkoły klasycznej nie znajdują odzwierciedlenia w otaczającej rzeczywistości gospodarczej. Najczęściej można spotkać się ze strukturami rynkowymi konkurencji niedoskonałej, czy nawet monopolem. Te struktury rynkowe są często wynikiem procesów koncentracji. Należy podkreślić, że istnienie innych niż konkurencja doskonała struktur rynkowych nie musi prowadzić do obniżenia dobrobytu społecznego. Niewątpliwie jednak istnienie oligopolu czy monopolu umożliwia i ułatwia takie zachowania przedsiębiorców, które ten dobrobyt obniżają. To powoduje, że procesy koncentracji przedsiębiorców nie są obojętne z punktu widzenia ochrony interesu publicznego. Ustawodawca ma zatem obowiązek określić, w jaki sposób procesy koncentracyjne będą poddane kontroli administracyjnej i które koncentracje będą przedmiotem badania ze strony organów państwa.

Funkcją kontroli koncentracji jest zapobieżenie powstaniu struktury rynku, która nie sprzyja istnieniu efektywnej konkurencji. Tego rodzaju struktura wiąże się najczęściej z powstaniem po stronie przedsiębiorcy istotnej siły rynkowej, choć niekoniecznie musi skutkować powstaniem pozycji dominującej ${ }^{2}$. Kontrola łączenia przedsiębiorstw służy bowiem nie tylko zapobieżeniu przyszłemu nadużywaniu uzyskanej pozycji, lecz także zachowaniu konkurencyjnej struktury rynkowej, która powinna prowadzić do zwiększenia dobrobytu społecznego i dobrobytu

2 K. Fountoukakos, S. Ryan, A New Substantive Test For Merger Control, „European Competition Law Review” 2005, no. 5, s. 280. 
konsumentów3 ${ }^{3}$ W tym celu organy ochrony konkurencji mają możliwość regulowania zmian w strukturze rynkowej przez decydowanie, czy dwóch lub więcej przedsiębiorców może dokonać koncentracji ${ }^{4}$. Poszukując specyfiki stosowania przepisów o kontroli łączenia przedsiębiorców, można wskazać, że kontrola koncentracji powinna być oparta na dogłębnej analizie każdej transakcji z uwzględnieniem jej gospodarczych implikacji ${ }^{5}$.

Antymonopolowa kontrola łączenia przedsiębiorców, stanowiąc wyjątek od zasady wolności gospodarczej, powinna być zatem ukształtowana w ten sposób, aby nie hamować naturalnych zmian rynkowych, ale powstrzymywać jedynie te, które mogą kształtować potencjalnie szkodliwe struktury rynkowe. $Z$ tego powodu organ antymonopolowy może interweniować, jeżeli stwierdzi istotne zagrożenie dla konkurencji. W odróżnieniu od lat 90. ubiegłego wieku kontrola koncentracji stała się bardziej elastyczna i w coraz mniejszym stopniu bazuje jedynie na formalnych regułach prawnych. Uelastycznieniu i zwiększeniu skuteczności kontroli koncentracji służy postępująca ekonomizacja prawa antymonopolowe$\mathrm{go}^{6}$. Podobnie zwiększeniu efektywności kontroli koncentracji o charakterze ponadnarodowym służy współpraca organów ochrony konkurencji.

\section{ROZWÓJ WSPÓŁPRACY MIĘDZYNARODOWEJ W SPRAWACH KONTROLI KONCENTRACJI}

Regulacje prawne dotyczące kontroli koncentracji przedsiębiorców rozwijają się w pełni dopiero od początku lat 90. XX w. Jeszcze na początku tego okresu jedynie ok. 20 krajów posiadało przepisy o kontroli koncentracji gospodarczej. W 2000 r. liczba ta się potroiła, obecnie zaś, według obliczeń $\mathrm{ICN}^{7}$, już ponad 100 krajów posiada ustawodawstwo dotyczące kontroli łączenia przedsiębiorców. Ten relatywnie późny rozwój przepisów o kontroli koncentracji tłumaczony jest tym, że kontrola koncentracji zawiera w sobie duży ładunek polityczny, a organy ochrony konkurencji, rozpatrując ważne sprawy koncentracyjne, są podatne na różne naciski polityczne. Druga przyczyna takiego późnego rozwoju tłumaczona

\footnotetext{
R. Whish, Competition Law, OUP, Oxford 2009, s. 806.

4 A. Jones, B. Sufrin, EC Competition Law. Text, Cases and Materials, OUP, Oxford 2008, s. 942.

J. Theeuwes, An Economic Analysis of the New Regulation 139/2004, „Legal Issues of Economic Integration” 2005, no. 2, s. 210.

6 M. Błachucki, Ekonomia jako podstawa i granica regulacji administracyjnoprawnej na przyktadzie przepisórw o antymonopolowej kontroli taczenia przedsiębiorców, [w:] S. Wrzosek, M. Domagała, J. Izdebski, T. Stanisławski (red.), Przeglad dyscyplin badawczych pokrewnych nauce prawa i postępowania administracyjnego, Lublin 2010, s. 482 i n.

7 Międzynarodowa Sieć Konkurencji (ang. International Competition Network).
} 
jest skomplikowaniem materii, albowiem stworzenie efektywnych ram prawnych do oceny koncentracji i przewidywania jej skutków jest niezwykle trudne, ponieważ taka regulacja może być obciążona dużym ryzykiem i wiązać się z dużymi kosztami ${ }^{8}$. Jednakże pomimo tych wstępnych trudności obecnie podkreśla się, że rozwój i rozprzestrzenienie się krajowych przepisów o kontroli łączenia przedsiębiorców może być uważane za ważny znak międzynarodowego uznania istotnej roli otwartych rynków i właściwego funkcjonowania mechanizmów rynkowych" Jest swego rodzaju paradoksem, że przepisy o kontroli koncentracji, które formalnie ograniczają wolność gospodarczą, są w swej istocie stworzone dla jej ochrony. $\mathrm{Ma}$ to istotne znaczenie wobec liberalizacji światowego handlu i coraz bardziej rozprzestrzeniającej się zasady swobodnego przepływu kapitału, albowiem zwiększa to możliwość oddziaływania jednej firmy na wiele rynków krajowych i rodzi wiele zagadnień natury formalnej.

Proces globalizacji, tworzenie się międzynarodowych przedsiębiorstw i korporacji powoduje, że coraz częstszym zjawiskiem stają się sytuacje, kiedy jedna transakcja podlega obowiązkowi zgłoszenia w wielu państwach ${ }^{10}$. Sytuacje takie określane są mianem koncentracji wielojurysdykcyjnych (ang. multi-jurisdictional mergers) lub koncentracji ponadnarodowych (ang. transnational mergers). Ocenia się, że ok. dwadzieścia kilka procent wszystkich koncentracji na świecie ma transnarodowy charakter ${ }^{11}$. $Z$ punktu widzenia samego przedsiębiorcy rodzi to wiele problemów praktycznych związanych z koniecznością notyfikacji transakcji w kilku czy nawet kilkudziesięciu krajach, które posiadają różne przepisy dotyczące kryteriów zgłaszania i oceny koncentracji. Często także różne są procedury i terminy rozpatrywania spraw koncentracji przedsiębiorców. Skutkuje to istotnym wzrostem kosztów transakcyjnych, a przede wszystkim zwiększeniem niepewności prawnej, co przy największych transakcjach jest wysoce niepożądane.

$\mathrm{Z}$ tego typu koncentracjami wiąże się wiele interesujących kwestii. Po pierwsze, wskazują one na konieczność rozgraniczenia kompetencji pomiędzy krajowymi organami ochrony konkurencji oraz, w przypadku państw członkowskich

8 D. J. Gerber, Global Competition: Law, Markets, and Globalization, OUP, Oxford 2010, s. 313 i 314 .

9 S. Wong, Internationalisation of Merger Review: Some Challenges in Designing an Effective System, [w:] M. Krasnodębska-Tomkiel (red.), Zmiany w polityce konkurencji na przestrzeni ostatnich dwóch dekad, UOKiK, Warszawa 2010, s. 267.

10 Wpływ procesu globalizacji na prawo konkurencji i krajowe porządki prawne nie dotyczy wyłącznie kontroli koncentracji, ale ma aspekt szerszy i dotyczy całego prawa antymonopolowego. Na temat tego wpływu oraz możliwości rozwiązywania problemów z nim związanych zob. A. S. Grewlich, Globalisation and Conflict in Competition Law. Elements of Possible Solutions, „World Competition" 2001, no. 3, s. 367 i n.

11 A. S. Papadopoulos, The international dimension of EU competition law and Policy, CEU, Cambridge 2010, s. 43. 
UE, rozgraniczenia kompetencji pomiędzy krajowymi organami ochrony konkurencji a Komisją Europejską, a także wspólpracy pomiędzy tymi instytucjami w zakresie rozpatrywanych spraw. Rozgraniczenie jurysdykcji krajowych oraz unikanie rozbieżności w ocenie tych samych koncentracji bywa istotnym problemem, szczególnie wtedy, kiedy rozpatrywana koncentracja wielojurysdykcyjna dotyczy championów krajowych lub innych przedsiębiorców o istotnym znaczeniu dla gospodarki krajowej. Wydaje się, że nawet postępująca konwergencja nie zlikwiduje do końca tych zagrożeń, co jest związane z silnym ładunkiem polityki zawartym w systemie kontroli koncentracji ${ }^{12}$. Po drugie, powodują intensyfikację współpracy międzynarodowej i skłaniają państwa lub organizacje międzynarodowe do zawierania umów międzynarodowych w przedmiocie współdziałania przy rozpatrywaniu spraw z zakresu kontroli koncentracji. Po trzecie, dają one asumpt do prób tworzenia dobrych praktyk i wytycznych w zakresie kształtowania krajowych przepisów proceduralnych i materialnych dotyczących kontroli łączenia przedsiębiorstw. Próby te podejmowane są na forach organizacji międzynarodowych, w szczególności Organizacji Współpracy Gospodarczej i Rozwoju, oraz na wirtualnych platformach wspólpracy, takich jak Międzynarodowa Sieć Konkurencji czy ECA ${ }^{13}$.

Zacieśnienie i zharmonizowanie współpracy międzypaństwowej w zakresie kontroli koncentracji jest korzystne zarówno dla organów ochrony konkurencji, jak i dla samych przedsiębiorców z dwóch powodów. Po pierwsze, pozwala instytucjom publicznym na szybsze i efektywniejsze rozpatrywanie spraw z zakresu kontroli łączenia przedsiębiorstw. Osiąga się to dzięki wymianie informacji, a czasem dowodów i konfrontowaniu przeprowadzanych analiz. W niektórych sytuacjach może także prowadzić do uniknięcia podjęcia przeciwstawnych rozstrzygnięć. Po drugie, zmniejsza niepewność prawną stron związaną z przeprowadzoną transakcją i prowadzi zazwyczaj do zmniejszenia kosztów transakcyjnych. Może również prowadzić do szybszego zamknięcia transakcji, co ma niebagatelne znaczenie wobec dynamiki procesów rynkowych.

Należy podkreślić także, że za współpracą między krajowymi organami ochrony konkurencji przemawiają dwa kolejne powody. Po pierwsze, należy zwrócić uwagę na fakt, że w zglobalizowanej gospodarce uczestnicy koncentracji mogą tworzyć skomplikowane i wielopoziomowe grupy kapitałowe oraz współpracować $\mathrm{z}$ wieloma kontrahentami (dostawcami, odbiorcami etc.), którzy nie muszą być bezpośrednio obecni na terytorium Polski. To powoduje, że czasami konieczne staje się przeprowadzanie czynności dowodowych poza granicami naszego

12 O. Budzinski, The Governance of Global Competition. Competence Allocation in International Competition Policy, Edward Elgar, Cheltenham-Northampton 2008, s. 45.

13 Europejskie Organy Konkurencji (ang. European Competition Authorities). 
kraju. Rodzi to wiele problemów prawnych, o których będzie mowa w dalszej części pracy. Po drugie, należy wziąć pod uwagę okoliczność będącą konsekwencją pierwszej obserwacji, tj. że nawet koncentracje o wymiarze krajowym, notyfikowane wyłącznie w jednym państwie, mogą oddziaływać na rynki oraz przedsiębiorców w innych krajach. Okres autarkiczności gospodarek krajowych przeminął już dawno, co powoduje, że współzależność gospodarek narodowych jest znaczna. Nawet jeżeli przedsiębiorca ma siedzibę w jednym kraju, może operować na wielu rynkach krajowych czy rynku globalnym. Powoduje to, że koncentracje z udziałem takiego przedsiębiorcy nie pozostają obojętne dla krajów, gdzie obecne są jego towary lub usługi, co wymusza wspólpracę krajowych organów ochrony konkurencji zarówno na etapie kontroli zamiaru koncentracji, jak i w trakcie wykonywania decyzji podjętej w tej sprawie.

Jak wskazano wyżej, konsekwencją internacjonalizacji i europeizacji procesów koncentracji jest wzrost współpracy krajowych organów ochrony konkurencji, który przybiera postać wirtualnych sieci współpracy, tj. ICN oraz ECA. W mojej opinii, okoliczność ta stanowi istotną cechę międzynarodowej i europejskiej wspólpracy organów antymonopolowych w dziedzinie kontroli koncentracji. W odróżnieniu bowiem od współpracy w dziedzinie przeciwdziałania antykonkurencyjnym praktykom przedsiębiorców, współpraca w dziedzinie kontroli koncentracji jest dobrowolna, odformalizowana i opiera się na instrumentach soft law oraz miękkiej adaptacyjności członków sieci.

\section{FORA I ŚRODKI WSPÓŁPRACY MIĘDZYNARODOWEJ W SPRAWACH KONTROLI KONCENTRACJI}

Analizując istniejącą mozaikę środków i forów międzynarodowej współpracy w sprawach koncentracji transnarodowych, można wskazać, że szczególnie w ostatniej dekadzie mieliśmy do czynienia z ogromnym wzrostem intensywności tej współpracy. Przyczyny takiego stanu rzeczy zostały wskazane wyżej, natomiast w tym momencie można się zastanowić nad klasyfikacją tych form współpracy. $Z$ punktu widzenia efektów współpracy fora i środki współpracy możemy podzielić na dwie kategorie:

1. Fora analityczne i poświęcone tworzeniu najlepszych praktyk - są to przykładowo OECD ${ }^{14}, \mathrm{ICN}, \mathrm{ECA}, \mathrm{MWG}^{15}$ (EU). Celem tych instytucji jest przede wszystkim rozwijanie wzajemnych kontaktów oraz wymiana doświadczeń. Wspólne dyskusje pozwalają na lepsze rozumienie zachodzących zjawisk w gospodarce oraz opracowanie reguł ich interpretacji. Takie

\footnotetext{
14 Organizacja Współpracy Gospodarczej i Rozwoju.
}

15 Grupa Robocza ds. Koncentracji. 
wspólne analizy są często podstawą do pójścia krok dalej i stworzenia powszechnie akceptowanych wspólnych zasad. Zasady te nie mają charakteru prawnie wiążącego, jednak stanowią wyraz chęci współpracujących organów uzgodnienia praktyki administracyjnej.

2. Fora poświęcone współpracy administracyjnej oraz wymianie informacji i dowodów - np. ECA, MWG (EU), czy też dwustronne lub wielostronne umowy międzynarodowe. Instytucje te stwarzają najdalej idące mechanizmy administracyjnej i prawnej współpracy pomiędzy zaangażowanymi państwami. Trudność w implementacji tych umów związana jest $\mathrm{z}$ różnym poziomem ochrony tajemnic i często odmiennymi zasadami dostępu do dokumentów publicznych i akt postępowania obowiązującymi w różnych krajach. Powoduje to, że państwa czy krajowe organy ochrony konkurencji dość rzadko decydują się na przyznanie dalej idących praw na mocy takich umów swoim zagranicznym odpowiednikom. Często także przepisy krajowe zawierają istotne ograniczenia dla takiej współpracy.

Jak widać $z$ tej krótkiej klasyfikacji, niektóre organizacje i fora międzynarodowe mogą pełnić dwojakie funkcje. $Z$ jednej strony mogą stanowić zaplecze analityczne tworzące porozumienie na poziomie rozumienia używanych pojęć, koncepcji oraz metodologii rozpatrywania spraw koncentracji przedsiębiorców. Kolejnym etapem współpracy jest tworzenie uzgodnionych najlepszych praktyk lub innych wytycznych zawierających konsensualne normy służące ujednoliceniu praktyki administracyjnej. Końcowym efektem takiej współpracy może być tworzenie ram prawnych dla współpracy administracyjnej i prawnej przy prowadzeniu spraw koncentracji przedsiębiorców. Wydaje się, że taka sytuacja jest pożądana, albowiem pozwala każdemu państwu na wybór rodzaju i intensywności współpracy. Warto też zauważyć, że pomimo różnorodności organizacji i forów, tworzą je często w dużej części te same podmioty. To także pogłębia wzajemne zrozumienie i sprzyja miękkiej adaptacji i wdrażaniu wspólnych standardów.

W prezentacji poniżej ujęto jedynie te organizacje i fora międzynarodowe, których działalność realnie dotyka kontroli koncentracji. $Z$ tego względu pominięto dorobek $\mathrm{WTO}^{16}$ czy UNCTAD ${ }^{17}$, które choć aktywne w dziedzinie polityki konkurencji, to w zakresie kontroli łączenia przedsiębiorców nie mają znaczących osiągnięć i znaczenia. Szczególnie przypadek WTO może być w tym zakresie pouczający, gdyż jest widomym fiaskiem niechęci państw do pełnego przejścia od miękkich form współpracy do „twardego” prawa i wyzbycia się części suwerenności w stosunku do niektórych koncentracji transnarodowych ${ }^{18}$.

\footnotetext{
Światowa Organizacja Handlu.

Konferencja Narodów Zjednoczonych ds. Handlu i Rozwoju.

18 Szerzej analizują to D. Liakopulos, A. Marsilia, The Regulation of Transnational Mergers in International and Europa Law, Martinus Nijhoff, Leiden-Boston 2010, s. 143 i n.
} 


\section{UNIA EUROPEJSKA}

Akcesja Polski do Unii Europejskiej wywarła istotny wpływ na system ochrony konkurencji w Polsce. W zakresie kontroli łączenia przedsiębiorstw pojawiła się kwestia podziału kompetencji pomiędzy Komisję oraz Prezesa UOKiK. Sprawę tę normuje Rozporządzenie Rady nr 139/2004 z dnia 20 stycznia 2004 r. w sprawie kontroli koncentracji przedsiębiorstw ${ }^{19}$, dalej także jako „EUMR”, oraz Rozporządzenie Komisji nr 802/2004 z dnia 7 kwietnia 2004 r. w sprawie wykonania rozporządzenia Rady (WE) nr 139/2004 w sprawie kontroli koncentracji przedsiębiorstw ${ }^{20}$, dalej także jako „Rozporządzenie wykonawcze”. EUMR wprowadza podział kompetencji pomiędzy Komisją Europejską i organami ochrony konkurencji państw członkowskich UE, ustanawiając zasadę, że wyłącznie Komisja rozpatruje koncentracje o wymiarze wspólnotowym (zasada ,jednego organu”, ang. one-stop-shop $)^{21}$, a państwa członkowskie nie mogą stosować przepisów krajowych do takich koncentracji. Podobna zasada obowiązuje w stosunku do koncentracji o wymiarze krajowym, które podlegają wyłącznej właściwości krajowych organów antymonopolowych, a Komisja nie ma w tym zakresie żadnych kompetencji. Od tych zasad obowiązują wszakże wyjątki, tzn. istnieje możliwość, że sprawy koncentracyjne o wymiarze krajowym rozpatrzy Komisja oraz że sprawy koncentracyjne o wymiarze wspólnotowym rozpatrzy antymonopolowy organ krajowy, np. Prezes UOKiK. W celu usprawnienia systemu alokacji spraw z zakresu kontroli koncentracji oraz wyjaśnienia stosowanych przepisów EUMR Komisja wydała Obwieszczenie Komisji w sprawie odsyłania spraw dotyczących koncentracji przedsiębiorców ${ }^{22}$. Podkreśla się, że rozgraniczenie kompetencji pomiędzy Komisją oraz organami krajowymi ochrony konkurencji wymaga elastycznej wykładni przepisów opartej na kryterium funkcjonalistycznym. Dodatkowo nie można zapominać, że kwestia ta niesie ze sobą duży ładunek polityczny, co powoduje, że odnośne przepisy EUMR mają charakter wypadkowej gry różnych interesów i wartości²3.

Ważną cechą unijnego prawa konkurencji, o której mowa była wcześniej, jest szeroki zakres zastosowania soft law w postaci różnego rodzaju obwieszczeń, wytycznych i not. W związku z tym, aby w sposób prawidłowy odtworzyć stan prawny $^{24}$, należy także zapoznać się $\mathrm{z}$ tymi aktami stosowania prawa ${ }^{25}$. Taka

19 Dziennik Urzędowy WE L 24, z 29.01.2004, s. 1-22.

20 Dziennik Urzędowy WE L 133, z 30/04/2004, s. 1-39.

21 Ust. 8 preambuły EUMR.

22 Dziennik Urzędowy C 56, z 05.03.2005, s. 2-23.

23 R. Burnley, An Appropriate Jurisdictional Trigger for the EC Merger Regulation and the Question of Decentralisation, „World Competition” 2002, no. 3, s. 266 i 267.

${ }_{24}$ Przynajmniej sposób, w jaki widzi go Komisja.

25 Należy wymienić tu: Obwieszczenie Komisji. Wytyczne w sprawie niehoryzontalnego połączenia przedsiębiorstw na mocy rozporządzenia Rady w sprawie kontroli koncentracji przed- 
analiza może spowodować, że sprawa, która początkowo wydawała się mieć charakter wspólnotowy, ma jednak wymiar krajowy (lub na odwrót). Przykładem może być tu rozpatrywana przez Prezesa UOKiK sprawa przejęcia przez JMD sieci dyskontów Plus. W sprawie tej, pomimo że prima facie wydawało się, że ma ona wymiar wspólnotowy (zostały spełnione przesłanki obrotu przedsiębiorców), Komisja, powołując się na swoje obwieszczenie, uznała, że sprawa winna być rozpoznana przez polski organ antymonopolowy ${ }^{26}$. Pokazuje to, że akty typu soft law są skierowane nie tylko do przedsiębiorców, ale także do innych krajowych organów administracji. Rola tych aktów wzrasta w przypadku organów administracji uczestniczących w sieci, gdyż stanowi formę komunikacji pomiędzy członkami sieci.

W styczniu 2010 r. przy Komisji została powołana Grupa Robocza ds. Koncentracji (Merger Working Group - MWG). Grupa ta składa się z reprezentantów Komisji Europejskiej oraz krajowych organów konkurencji krajów EOG. Celem współpracy w ramach grupy roboczej jest pogłębienie konwergencji i współpracy pomiędzy porządkami i organami krajowymi w celu zapewnienia skutecznej administracji i wdrażania kontroli koncentracji. MWG jest pierwszym na poziomie unijnym ciałem poświęconym wyłącznie współpracy w dziedzinie kontroli

siębiorstw, http://ec.europa.eu/comm/competition/mergers/legislation/nonhorizontalguidelines. pdf (06/10/09); Wytyczne w sprawie oceny horyzontalnego połączenia przedsiębiorstw na mocy rozporządzenia Rady w sprawie kontroli koncentracji przedsiębiorstw (Dziennik Urzędowy C 31, z 05.02.2004, s. 5-18); Obwieszczenie Komisji w sprawie definicji rynku właściwego do celów wspólnotowego prawa konkurencji (Dziennik Urzędowy C 372, z 09.12.1997, s. 5). Spośród innych dokumentów Komisji znaczenie dla postępowania w sprawach koncentracji mają także: Obwieszczenie Komisji w sprawie środków zaradczych dopuszczalnych na mocy rozporządzenia Rady (EWG) nr 4064/89 i rozporządzenia Komisji (WE) nr 447/98 (Dziennik Urzędowy C 68, z 02.03.2001, s. 3); Komunikat Komisji w sprawie ograniczeń bezpośrednio związanych i koniecznych dla dokonania koncentracji (Dziennik Urzędowy C 56, z 05.03.2005, s. 24-31); Obwieszczenie Komisji w sprawie uproszczonej procedury stosowanej do niektórych koncentracji na mocy rozporządzenia Rady (WE) nr 139/2004 (Dziennik Urzędowy C 056, z 05/03/2005, s. 32-35); Decyzja Komisji 2001/462 z dnia 23 maja 2001 r. w sprawie zasad uczestnictwa urzędników ds. wysłuchań w niektórych postępowaniach z zakresu ochrony konkurencji (Dziennik Urzędowy L 162, z 19.06.2001, s. 21-24); Nota informacyjna Dyrekcji Generalnej ds. Konkurencji dotycząca art. 6 ust. 1 lit. c drugie zdanie Rozporządzenia 139/2004 (odstąpienie od koncentracji), http://ec.europa.eu/comm/competition/mergers/legislation/abandonment.pdf (06/10/09); Skonsolidowane obwieszczenie Komisji dotyczące kwestii jurysdykcyjnych, http://ec.europa.eu/comm/competition/ mergers/legislation/draft_jn.html (06/10/08); DG Competition Best Practices on the conduct of EC merger proceedings 20/01/2004 (brak jest oficjalnego polskiego tlumaczenia), http://ec.europa. eu/competition/mergers/legislation/proceedings.pdf (06/10/08).

${ }_{26}$ Zgodnie ze wspomnianymi Wytycznymi w sprawie oceny horyzontalnego połączenia przedsiębiorstw na mocy rozporządzenia Rady w sprawie kontroli koncentracji przedsiębiorstw obrót przedsiębiorców ustala się na podstawie ostatnich zacytowanych obrotów. W omawianej sprawie jedynie szacunkowe obroty wskazywały na osiągnięciu wartości określonej w art. 1 ust. 2 EUMR, w świetle zaś dostępnych ostatnich zaudytowanych obrotów wartości te nie zostały osiągnięte. W konsekwencji sprawę rozpoznał Prezes UOKiK. 
koncentracji. Pierwszym efektem prac grupy jest opracowanie najlepszych praktyk w zakresie współpracy pomiędzy krajowymi organami ochrony konkurencji $\mathrm{w}$ procesie kontroli koncentracji $\mathrm{i}^{27}$.

\section{OECD}

Organizacja Współpracy Ekonomicznej i Rozwoju (ang. OECD - Organisation for Economic Cooperation and Development), zgodnie ze swoją Konwencją z 1960 r. ${ }^{28}$, została powołana m.in. w celu osiągania jak najwyższego trwałego wzrostu gospodarczego i zatrudnienia oraz rosnącego poziomu życia w państwach członkowskich, przy utrzymaniu stabilizacji finansowej, a przez to przyczyniania się do rozwoju gospodarki światowej. Jedną ze sfer aktywności OECD, jest wspólpraca w zakresie polityki konkurencji. Jak stanowi art. 5 Konwencji OECD, organizacja ta może dla osiągania swoich celów przedkładać zalecenia (rekomendacje) państwom członkowskim. Należy wskazać, że tym, co wyróżnia rekomendacje OECD oraz w ogóle działalność tej organizacji na tle innych form współpracy międzynarodowej, jest powiązanie kwestii polityki konkurencji z kwestią wzrostu gospodarczego ${ }^{29}$. Objawia się to szerszym i głębszym spojrzeniem na analizowane zagadnienia. Dzięki stałej i relatywnie dużej strukturze administracyjnej tej organizacji dokumenty OECD wyróżniają się jakością i kompleksowością analiz.

Problematyki kontroli koncentracji dotyczy rekomendacja Rady z 23 marca 2005 r. $^{30}$, zwana „Rekomendacją OECD z 2005 r.” Przyjęcie tego zalecenia poprzedzily dwa raporty przygotowane w $1994 \mathrm{r}^{31}$ i $1999 \mathrm{r}^{32}$ Przyczyną przyjęcia Rekomendacji OECD z 2005 r. była rosnąca liczba koncentracji transnarodowych, z czym wiążą się duże koszty dla przedsiębiorców oraz wzmożona potrzeba koordynacji działań narodowych organów ochrony konkurencji. W szczególności, współpraca pomiędzy krajowymi organami antymonopolowymi winna obejmować wymianę doświadczeń oraz informacji o prowadzonych postępowaniach. W porównaniu do poprzednio omawianej rekomendacji, Rekomendacja OECD

27 http://ec.europa.eu/competition/consultations/2011_merger_best_practices/en.pdf $(01 / 10 / 11)$.

28 Konwencja o Organizacji Współpracy Gospodarczej i Rozwoju (OECD) z dnia 14 grudnia 1960 r., Dz. U. z 1998 r., nr 76, poz. 490.

29 B. Michalski, Międzynarodowa koordynacja polityki konkurencji, Difin, Warszawa 2009, s. 119 i 120 .

30 OECD Recommendation of the Council on Merger Review [C(2005)34/Final], http:// webdomino1.oecd.org/horizontal/oecdacts.nsf/linkto/c(2005)34 (09/10/08).

31 Merger Cases in the Real World, A Study of Merger Control Cases, OECD, Paryż 1994.

32 Report on notification of transnational mergers, http://www.oecd.org/dataoecd/40/2/2752153.pdf (09/10/08). 
z 2005 r. zawiera ogólne wskazania odnośnie do ukształtowania krajowych przepisów dotyczących kontroli koncentracji przedsiębiorców. Wskazówki te wyznaczają pewien standard, który winien być osiągnięty przez państwa OECD, a jednocześnie ze swojej istoty nie mogą być zbyt szczególowe, aby nie naruszać wyłącznej kompetencji państw członkowskich do kształtowania przepisów krajowych.

\section{ECA}

ECA (ang. European Competition Authorities) to forum Europejskich Organów Konkurencji, które zostało powołane 20 kwietnia 2001 r. w Amsterdamie jako miejsce dyskusji i wymiany doświadczeń pomiędzy organami ochrony konkurencji krajów Europejskiego Obszaru Gospodarczego (EOG). W skład ECA wchodzą wszystkie państwa członkowskie UE (w tym Polska), Komisja, państwa Europejskiej Strefy Wolnego Handlu (ang. EFTA), tj. Norwegia, Islandia i Lichtenstein, a także Urząd Nadzoru EFTA (ang. EFTA Surveillance Authority). Celem tego forum jest poprawa wspólpracy pomiędzy krajowymi organami antymonopolowymi i wzmocnienie skutecznego stosowania krajowego i unijnego prawa konkurencji. W ramach współpracy w zakresie kontroli koncentracji na forum ECA przyjęto dwa dokumenty. Są to: Zasady stosowania przez krajowe organy ochrony konkurencji, w ramach ECA, art. 4 ust. 5 oraz 22 unijnego rozporządzenia w sprawie kontroli koncentracji ${ }^{33}$, oraz Przewodnik proceduralny - Wymiana informacji pomiędzy członkami ECA na temat wielojurysdykcyjnych koncentracji $^{34}$. Szczególne znaczenie ma drugi ze wspomnianych dokumentów, gdyż tworzy on realną i trwałą formę współpracy pomiędzy członkami ECA. Na podstawie tego uzgodnionego dokumentu wszystkie państwa członkowskie informują się wzajemnie o notyfikowanych na ich terytorium transakcjach wielojurysdykcyjnych. Przekazywane tą drogą są jedynie informacje publicznie dostępne, ale są one wystarczające do zainicjowania współpracy.

Status wspomnianych dokumentów jest taki sam. Nie mają one charakteru prawnie wiążącego, są natomiast deklaracją zamiaru przestrzegania przez członków ECA wyrażonych w tych dokumentach przepisów w granicach, jakie wynikają $\mathrm{z}$ kompetencji danego organu oraz odpowiednich krajowych przepisów.

33 Principles on the application, by National Competition Authorities within the ECA, of Articles 4 (5) and 22 of the EC Merger Regulation. Dostępne na http://www.bundeskartellamt.de/ ${ }_{w}$ Deutsch/download/pdf/Merkblaetter/Merkblaetter_englisch/ECA_Principles.pdf (1/10/09).

34 The exchange of information between members on multijurisdictional mergers. Procedures guide. Dostępne na: http://www.bundeskartellamt.de/wDeutsch/download/pdf/ECA/ECA_procedures_guide_post_Athens.pdf (1/10/09). 
Można dokumenty te zaliczyć zatem do kategorii soft law albo też prawa międzynarodowego administracyjnego ${ }^{35}$. Specyficzną cechą tych dokumentów jest ich język. Są one pisane językiem pełnym sformułowań nieostrych, często wziętych $\mathrm{z}$ języka prawniczego, a nie prawnego.

\section{ICN}

ICN (ang. International Competition Network) stanowi międzynarodowe forum zrzeszające rządowe agencje antymonopolowe oraz międzynarodowe organizacje, których celem jest ochrona konkurencji. Międzynarodowa Sieć Konkurencji powstała 25 października 2001 r. i skupia obecnie większość krajowych organów ochrony konkurencji. Podstawą jej działania jest przyjęte memorandum, które określa zasady działania tego forum ${ }^{36}$. Celem tej międzynarodowej platformy współpracy jest współdziałanie w zakresie wdrażania prawa konkurencji. ICN nie jest organizacją międzynarodową ani nie ma żadnych kompetencji władczych. Dzięki temu zrzesza o wiele więcej członków i jej potencjalny wpływ jest szerszy niż np. OECD ${ }^{37}$. Cechą charakterystyczną ICN jest jej otwarty charakter i dopuszczenie organizacji pozarządowych oraz przedstawicieli świata prawniczego i akademickiego do jej prac.

Dzięki nieformalnej organizacji oraz elastycznym metodom działania ICN stanowi forum wymiany myśli i poglądów, których efektem są wspólne rekomendacje oraz dobre praktyki. Dorobek ICN jest szczególnie widoczny w zakresie współpracy przy rozpatrywaniu wielojurysdykcyjnych koncentracji ${ }^{38}$. Pierwszym programowym dokumentem ICN z tego zakresu są Zasady przewodnie procedury zgłoszenia oraz rozstrzygania spraw koncentracji przedsiębiorców ${ }^{39}$. Zasady te można potraktować jako zasady ogólne, na podstawie których winny być konstruowane procedury kontroli łączenia przedsiębiorstw. W ramach ICN zostały także stworzone rekomendacje $\mathrm{w}$ zakresie materialnej oceny koncentracji ${ }^{40}$, a tak-

35 Na temat pojęcia międzynarodowego prawa administracyjnego zob. M. Zieliński, O pojęciu międzynarodowego prawa administracyjnego, „Państwo i Prawo” 2008, z. 9, s. 24 i 25.

36 Memorandum on the Establishment and Operation of the International Competition Network, http://www.internationalcompetitionnetwork.org/media/library/mou.pdf (04/10/08).

37 Y. Devellennes, G. Kiriazis, The creation of an International Competition Network, „Competition Policy Newsletter" 2002, no. 1, s. 26.

38 G. Roebling, S. A. Ryan, D. Sjoblom, The International Competition Network (ICN) two years on: concrete results of a virtual network, „Competition Policy Newsletter” 2003, no. 3, s. 38.

39 Guiding Principles For Merger Notification and Review, http://www.internationalcompetitionnetwork.org/media/library/conference_1st_naples_2002/icnnpworkinggroupguiding.pdf (04/10/08).

40 Recommended Practices For Merger Analysis, http://www.internationalcompetitionnetwork.org/media/library/Cartels/Merger_WG_1.pdf (03/10/09). 
że narzędzia przydatne przy prowadzeniu postępowania ${ }^{41}$ oraz przy postępowaniu dowodowym ${ }^{42}$. Co istotne, ICN wypracowała także narzędzia pomocne przy konstruowaniu krajowych przepisów z zakresu kontroli koncentracji ${ }^{43}$. W ramach ICN przygotowano też wiele różnych użytecznych raportów ${ }^{44}$.

\section{UMOWY I POROZUMIENIA MIĘDZYNARODOWE}

Do intensyfikacji współpracy w zakresie kontroli koncentracji wykorzystywane są wielostronne porozumienia międzynarodowe lub zawierane pomiędzy krajowymi organami ochrony konkurencji. Istnieje wiele regionalnych inicjatyw poświęconych wspólpracy we wdrażaniu prawa konkurencji ${ }^{45}$. Różnią się one w zależności od intensywności oraz efektów tej współpracy:

1. Współpraca miękka polegająca przede wszystkim na prowadzeniu rozmów politycznych i wymianie doświadczeń czy wspólnej organizacji seminariów i konferencji. Przykładowo Prezes UOKiK wspólnie z przedstawicielami czterech organów antymonopolowych państw Europy Środkowej, tj. Czech, Słowacji, Słowenii i Węgier, powołali 3 kwietnia 2003 roku Środkowoeuropejską Inicjatywę Współpracy Organów ds. Konkurencji (ang. Central European Competition Initiative - CECI). CECI ma na celu wzmocnienie wymiany doświadczeń z zakresu ochrony konkurencji pomiędzy jej państwami członkowskimi oraz organizację wspólnych przedsięwzięć, takich jak konferencje i szkolenia ${ }^{46}$.

41 ICN Merger Guidelines Workbook, http://www.internationalcompetitionnetwork.org/media/library/conference_5th_capetown_2006/ICNMergerGuidelinesWorkbook.pdf (03/10/09).

42 ICN Investigative Techniques Handbook for Merger Review, http://www.internationalcompetitionnetwork.org/media/library/conference_4th_bonn_2005/Investigative_Techniques_ Handbook.pdf (03/10/09).

43 Implementation Handbook, http://www.internationalcompetitionnetwork.org/media/library/conference_5th_capetown_2006/ImplementationHandbookApril2006.pdf (03/10/09).

${ }_{44}$ Defining "Merger" Transactions for Purposes of Merger Review, http://www.internationalcompetitionnetwork.org/media/library/conference_6th_moscow_2007/23ReportonDefiningM ergerTransactionsforPurposesofMergerReview.pdf (04/10/09); Report on the Costs and Burdens of Multijurisdictional Merger Review, http://www.internationalcompetitionnetwork.org/media/ library/conference_1st_naples_2002/costburd.pdf (04/10/09); Setting notification thresholds for merger review, http://www.internationalcompetitionnetwork.org/media/library/mergers/Merger_ WG_2.pdf (04/10/09); Merger Notification Filing Fees. A Report of the International Competition Network, http://www.internationalcompetitionnetwork.org/media/library/conference_4th_ bonn_2005/Filing_Fees.pdf(03/10/09).

45 Omówienie takich inicjatyw i porozumień zob. A. S. Papadopoulos, op. cit., s. 278 i n.

46 http://uokik.gov.pl/pl/wspolpraca_miedzynarodowa/wspolpraca_wielostronna/ceci/ (01/02/10). 
2. Współpraca wzmocniona zawierająca w sobie instrumenty współpracy miękkiej, ale wzmocniona stworzeniem wspólnych mechanizmów, które są wykorzystywane w bieżącej współpracy. Przykładem może być tutaj Forum Konkurencji Marchfeld powstałe w lipcu 2008 r., w Marchfeld w Austrii. Forum to powstało z inicjatywy Austrii i skupia reprezentantów organów ochrony konkurencji z Austrii, Bułgarii, Chorwacji, Czech, Estonii, Węgier, Łotwy, Litwy, Rumunii, Słowacji, Szwajcarii oraz Komisji Europejskiej (Dyrekcji Generalnej ds. Konkurencji). Polska formalnie nie uczestniczy w tym forum, ale blisko z nim współpracuje, wyrażając zainteresowanie jego działalnością. Celem powołania forum jest wzmocnienie regionalnej współpracy i koordynacji pomiędzy krajowymi organami ochrony konkurencji ${ }^{47}$. W ramach forum stworzona została baza wymiany informacji o rozpatrywanych przez poszczególne organy krajowe koncentracjach. Widać tutaj zatem pewien zalążek koordynacji działań i stworzenie realnych i trwałych mechanizmów współpracy.

3. Pełna współpraca administracyjna polega na wzajemnej pomocy administracyjnej przy prowadzeniu postępowań $\mathrm{w}$ sprawach koncentracji, w tym wymianie informacji oraz dowodów. Przykładem takiej kooperacji jest Współpraca Nordycka. Utworzyły ją 16 marca 2001 r. Dania, Islandia i Norwegia. Następnie dołączyły Grenlandia, Wyspy Owcze, Szwecja i Finlandia. Współpraca Nordycka obejmuje coroczne spotkania szefów organów ochrony konkurencji z zaangażowanych państw. Ponadto intensywna jest współpraca analityczna i tworzone są wspólne raporty poświęcone aktualnym zagadnieniom polityki konkurencji ${ }^{48}$. Cechą wyróżniającą Wspólpracy Nordyckiej jest zawarcie formalnej umowy międzynarodowej, która określa zasady współpracy administracyjnej. Zgodnie z art. 3 i 4 tej umowy możliwa jest wymiana dowodów zawierających informacje ogólnodostępne, jak i tajemnice przedsiębiorstw ${ }^{49}$.

Wzmocnienie współpracy międzynarodowej w sprawach kontroli koncentracji może być osiągnięte za pomocą zawieranych umów międzynarodowych. Większość tego rodzaju umów poświęcana jest ogólnym zagadnieniom polityki konkurencji. Co istotne, umowy te nie mają jednakowego statusu prawnego.

47 http://www.en.bwb.gv.at/InternationalCooperation/MarchfeldCompetitionForum/Seiten/ default.aspx (01/02/10).

$48 \mathrm{http}: / /$ www.kilpailuvirasto.fi/cgi-bin/english.cgi?luku=nordic-cooperation\&sivu=nordiccooperation $(01 / 02 / 10)$.

${ }_{49} \mathrm{http}: / /$ www.konkurransetilsynet.no/en/about/Nordic-co-operation-in-competition-cases-/ (01/02/10). 
Analiza zawartych przez Polskę umów wskazuje, że żadna z nich ${ }^{50}$ nie ma istotnego znaczenia dla systemu kontroli łączenia przedsiębiorców w Polsce. Taki stan nie jest zadowalający. W szczególności niedostatek ten widać w zakresie dwóch sfer: wzajemnego uznawania i egzekucji decyzji administracyjnych oraz pomocy prawnej $\mathrm{w}$ trakcie postępowania dowodowego, $\mathrm{w}$ tym wymiany dowodów. Pierwszy ze wskazanych problemów ma charakter szerszy i ujawnia się w szczególności w zakresie egzekucji nałożonych kar administracyjnych. W tym obszarze widać, że współpraca międzynarodowa jest niedorozwinięta w stosunku do współpracy obejmującej uznawanie i egzekucję wyroków sądowych. Drugi z problemów może być rozwiązany przez podpisanie umowy międzynarodowej albo wprowadzenie odpowiednich przepisów do ustawy antymonopolowej, upoważniających Prezesa UOKiK do udzielania pomocy prawnej oraz występowania o nią do innych krajowych organów ochrony konkurencji, a także do wymiany dowodów.

\section{ZAKOŃCZENIE}

Wspólpraca międzynarodowa przy rozpatrywaniu koncentracji wielojurysdykcyjnych wzrasta wraz ze wzrastającą liczbą koncentracji transnarodowych. Istnieje wiele form i środków tej współpracy. Każda $z$ instytucji ma swoją specyfikę, choć trudno jest oprzeć się wrażeniu, że w niektórych obszarach wysiłki się pokrywają. Nie unieważnia to bynajmniej poszczególnych form współpracy, ale sprawia, że dzięki temu osiągany jest jeszcze większy międzynarodowy consensus w zakresie prawa i praktyki administracyjnej. Co istotne także, jak wskazano wcześniej, umiędzynarodowienie kontroli koncentracji nie unieważnia także interesów narodowych, co może prowadzić do konfliktów przy rozpatrywaniu szczególnie dużych i ważnych transakcji ${ }^{51}$.

Współpraca międzynarodowa w odniesieniu do konkretnej sprawy koncentracyjnej będzie zależała od jej gospodarczego charakteru oraz od przepisów krajowych. Przepisy te będą wyznaczały granice rzeczywistej współpracy. O ile bowiem miękka wspólpraca stanowi podstawę rozwoju międzynarodowej kooperacji $\mathrm{w}$ sprawach konkurencji, to w konkretnym przypadku o najdalej idących, tj. administracyjnych i prawnych, formach wspólpracy będą decydowały przepisy krajowe. Warto jednak podkreślić, że pewien formalizm przepisów krajowych, w odróżnieniu do elastyczności międzynarodowych norm konsensualnych, nie

\footnotetext{
50 Poza umowami o powołaniu i przystąpieniu do organizacji międzynarodowych, o których mowa była wcześniej.

51 O. Budzinski, op. cit., s. 45 i n.
} 
ma na celu podważania lub opóźniania współpracy międzynarodowej, ale służy przede wszystkim ochronie praw przedsiębiorców zaangażowanych w procedury notyfikacyjne w wielu krajach członkowskich. Zapobiega bowiem arbitralnemu przekazywaniu informacji i niekontrolowanemu dostępowi do tajemnic przedsiębiorstw. Trzeba też pamiętać, że istnienie odrębności krajowych nie będzie miało w znakomitej większości sytuacji negatywnego wpływu na koncentracje wielojurysdykcyjne, co wynika $\mathrm{z}$ coraz bardziej jednolitego rozumienia podstawowych instytucji kontroli koncentracji i rzeczywistej konwergencji w zakresie dokonywanych analiz.

\section{BIBLIOGRAFIA}

Błachucki M., Ekonomia jako podstawa i granica regulacji administracyjnoprawnej na przyktadzie przepisów o antymonopolowej kontroli taczenia przedsiębiorców, [w:] S. Wrzosek, M. Domagała, J. Izdebski, T. Stanisławski (red.), Przeglad dyscyplin badawczych pokrewnych nauce prawa i postępowania administracyjnego, Lublin 2010.

Budzinski O., The Governance of Global Competition. Competence Allocation in International Competition Policy, Edward Elgar, Cheltenham-Northampton 2008.

Burnley R., An Appropriate Jurisdictional Trigger for the EC Merger Regulation and the Question of Decentralisation, „World Competition” 2002, no. 3.

Devellennes Y., Kiriazis G., The creation of an International Competition Network, „Competition Policy Newsletter" 2002, no. 1.

Gerber D. J., Global Competition: Law, Markets, and Globalization, OUP, Oxford 2010.

Grewlich A. S., Globalisation and Conflict in Competition Law. Elements of Possible Solutions, „World Competition” 2001, no. 3.

Fountoukakos K., Ryan S., A New Substantive Test For Merger Control, „European Competition Law Review" 2005, no. 5.

Jones A., Sufrin B., EC Competition Law. Text, Cases and Materials, OUP, Oxford 2008.

Krasnodębska-Tomkiel M., Wspólnotowe prawo konkurencji. Skutki dla Polski (stan prawny na dzień 01.05.2004), Urząd Ochrony Konkurencji i Konsumentów, Warszawa 2005.

Liakopulos D., Marsilia A., The Regulation of Transnational Mergers In International and Europa Law, Martinus Nijhoff, Leiden-Boston 2010.

Michalski B., Międzynarodowa koordynacja polityki konkurencji, Difin, Warszawa 2009.

Papadopoulos A. S., The international dimension of EU competition law and Policy, CEU, Cambridge 2010.

Roebling G., Ryan S. A., Sjoblom D., The International Competition Network (ICN) two years on: concrete results of a virtual network, „Competition Policy Newsletter” 2003, no. 3.

Theeuwes J., An Economic Analysis of the Nerw Regulation 139/2004, „Legal Issues of Economic Integration" 2005, no. 2.

Whish R., Competition Law, OUP, Oxford 2009. 
Wong S., Internationalisation of Merger Review: Some Challenges in Designing an Effective System, [w:] M. Krasnodębska-Tomkiel (red.), Zmiany w polityce konkurencji na przestrzeni ostatnich dwóch dekad, UOKiK, Warszawa 2010.

Zieliński M., O pojęciu międzynarodowego prawa administracyjnego, „Państwo i Prawo” 2008, z. 9.

\section{STRESZCZENIE}

Proces globalizacji, tworzenie się międzynarodowych przedsiębiorstw i korporacji powoduje, że coraz częstszym zjawiskiem stają się sytuacje, kiedy jedna transakcja koncentracyjna podlega kontroli w wielu państwach. Sytuacje takie określane są mianem koncentracji wielojurysdykcyjnych (ang. multi-jurisdictional mergers) lub koncentracji ponadnarodowych (ang. transnational mergers). Przedmiotem artykułu są zagadnienia prawne, w szczególności z zakresu prawa konkurencji, które wyłaniają się na tle kontroli transnarodowych procesów koncentracji. Zakresem analizy zostały objęte m.in. zagadnienia rozgraniczenia kompetencji pomiędzy krajowymi organami ochrony konkurencji oraz, w przypadku państw członkowskich UE, rozgraniczenia kompetencji pomiędzy krajowymi organami ochrony konkurencji a Komisją, a także współpracy pomiędzy tymi instytucjami w zakresie rozpatrywanych spraw. Ponadto ukazana została intensyfikacja współpracy międzynarodowej, która skłania państwa lub organizacje międzynarodowe do zawierania umów międzynarodowych w przedmiocie współdziałania przy rozpatrywaniu spraw z zakresu kontroli koncentracji. Omówiona została działalność organizacji międzynarodowych aktywnych w promowaniu współpracy w zakresie kontroli koncentracji transnarodowych.

\section{INTERNATIONALIZATION OF MERGER CONTROL}

\section{SUMMARY}

Globalization and the establishment of transnational corporations lead to a situation, where the same concentration is reviewed in parallel by different national competition authorities. Such mergers are described as multi-jurisdictional mergers or transnational mergers. The article deals with legal issues that arise in connection with the process of control of multi-jurisdictional mergers. The author concludes that cooperation between competition authorities in merger cases is growing together with the growing number of multijurisdictional mergers. Furthermore there are various forums of cooperation and each has its characteristics, but to some extent they might be overlapping in some instances. Depending on national barriers the actual scope of cooperation may differ in a particular case. The variety of cooperation forums serves to create a real network of merger control authorities and people. This is crucial for successful cooperation in merger cases and should bring speedy and coherent results. 
